\title{
A Biopsy-Proven Case of Acute Oxalate Nephropathy from Longevity Remedies
}

\author{
Sukit Raksasuk* and Thatsaphan Srithongkul \\ Division of Nephrology, Faculty of Medicine Siriraj Hospital, Thailand \\ *Corresponding author: Sukit Raksasuk, Division of Nephrology, Faculty of Medicine Siriraj Hospital, Thailand
}

\begin{tabular}{|c|c|}
\hline ARTICLE INFO & ABSTRACT \\
\hline Received: 蔧 June 27, 2019 & Acute oxalate nephropathy is an uncommon etiology of acute kidney injury caused by \\
\hline Published: 慧 July 10, 2019 & $\begin{array}{l}\text { deposition of oxalate crystals in the kidneys as a result of hyperoxaluria. We report a case } \\
\text { of biopsy-proven acute oxalate nephropathy after excessive consumption of } A \text {. bilimbi fruit }\end{array}$ \\
\hline
\end{tabular}

Citation: Sukit Raksasuk, Thatsaphan Srithongkul. A Biopsy-Proven Case of Acute Oxalate Nephropathy from Longevity Remedies. Biomed J Sci \& Tech Res 19(3)-2019. BJSTR. MS.ID.003314.

\section{Case Report}

A 66-year-old man with past medical history of hypertension and type 2 diabetes mellitus presented with generalized edema for 7 days. He noticed that his urine volume was significantly decreased but denied history of foamy urine or gross hematuria. He also denied history of vomiting, diarrhea, difficult urination, fever and recent exposure to nephrotoxic medications. Physical examination revealed a stable vital sign, but his eye lids were puffy and pitting edema was observed on both legs. Initial laboratory investigations revealed BUN of $29 \mathrm{mg} / \mathrm{dL}$, creatinine of $6.2 \mathrm{mg} /$ $\mathrm{dL}$ and normal serum electrolyte. His prior creatinine that was done 4 months ago was $1.4 \mathrm{md} / \mathrm{dL}$. His urinalysis was negative for proteinuria and cells. Ultrasonogram of the kidneys and urinary tract was normal without stone or hydronephrosis. Upon further interview, he admitted that he ate 4-5 A. bilimbi fruits preserved in syrup and $250 \mathrm{ml}$ of their juice per day for the past 10 days as herbal remedies for longevity. Further investigations revealed 24hour urine volume of $848 \mathrm{~mL}$ and 24-hour urine oxalate of 15.77 $\mathrm{mg}(1.76 \mathrm{mmol})$. The oxalate concentration of the juice was 483.49 $\mathrm{mg} / \mathrm{dL}(53.72 \mathrm{mmol} / \mathrm{dL})$.

We decided to perform percutaneous renal biopsy to evaluate for the definite cause of his acute kidney injury and the renal pathology showed evidence of diffused tubular injury with multiple foci of interlobular calcium oxalate crystals (Figures 1 \& 2). During the course of his hospitalization, this patient was restrained from oxalate-containing food and received intravenous fluid. His renal function gradually recovered, and his serum creatinine declined from $6.2 \mathrm{mg} / \mathrm{dL}$ to $5.2 \mathrm{mg} / \mathrm{dL}$ within 2 weeks and returned to near baseline level $(2.3 \mathrm{mg} / \mathrm{dL})$. Since urinary excretion is one the main pathways for eradication of oxalate [1], excessive dietary oxalate intake can trigger renal damage as supersaturated oxalate in the urine and bind with calcium, causing crystallization of oxalate in the renal tubules and interstitium, which lead to inflammation and injury to the kidneys [2,3]. A. bilimbi is another fruit that contains a high amount of oxalate. Previous studies have demonstrated that the concentration of oxalate in A. bilimbi fruit could range from 8.6 to $10.3 \mathrm{~g} / 100 \mathrm{~g}$ depends on the ripeness and season [4].
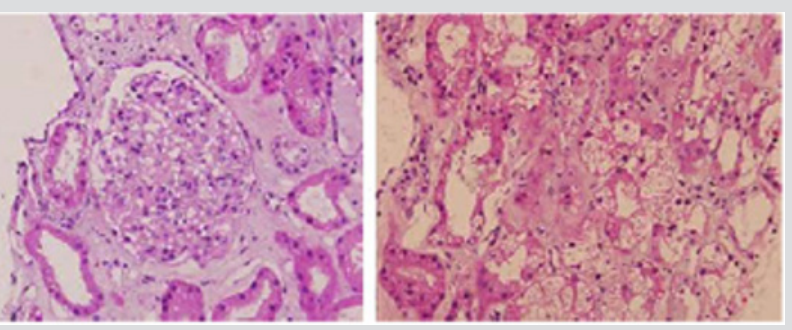

Figure 1:

a) Left: normal glomerulus.

b) Right: widening of tubular lumen and tubular cell destruction with mononuclear cell infiltration in the interstitium. (Hematoxylin and eosin, $40 \mathrm{X}$ ). 

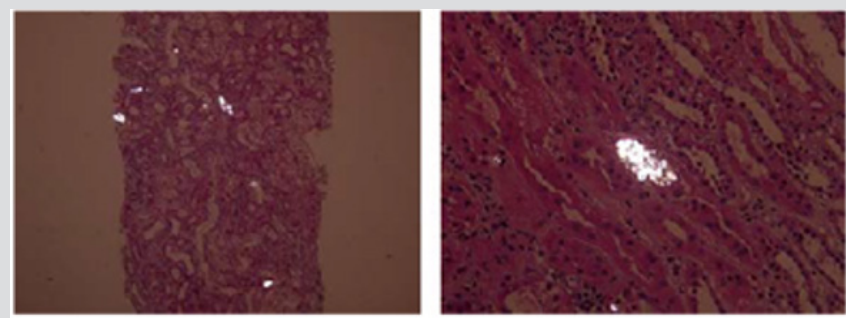

Figure 2:

a) Left: multiple calcium oxalate crystals in tubular lumens with tubular atrophy and interstitial fibrosis.

b) Right: calcium oxalate crystal detected by polarized light microscopy-birefringent and organizing in rosette shape. (Polarized hematoxylin and eosin, 40X).

This fruit is widely used by the residences of the tropical countries as herbal remedies for several illnesses $[5,6]$. This case report may serve a reminder that excessive consumption of $A$. bilimbi fruit is a potential cause of acute kidney injury and may underscore the importance of dietary history as a clue to the correct diagnosis. In fact, there are also a number of previous reports that have described cases of acute oxalate nephropathy after consumption of $A$. bilimbi fruit [5-7]. The degree of renal impairment in the reports ranged from mild acute kidney injury to acute renal failure requiring hemodialysis although the overall prognosis was generally favorable as all of the described patients had a renal recovery within 4-6 weeks with supportive care and avoidance of oxalate-rich diet similar to our patient.

\section{References}

1. Holmes RP, Goodman HO, Assimos DG (2001) Contribution of dietary oxalate to urinary oxalate excretion. Kidney Int 59(1): 270-276.

2. Lorenz EC, Michet CJ, Milliner DS, Lieske JC (2013) Update on oxalate crystal disease. Curr Rheumatol Rep 15(7): 340.

3. Mulay SR, Anders HJ (2017) Crystal nephropathies: mechanisms of crystal-induced kidney injury. Nat Rev Nephrol 13(4): 226-240.

4. Vera Lúcia Arroxelas Galvão De Lima, Enayde De Almeida Mélo, Lueci Dos Santos Lima (2001) physicochemical characteristics of bilimbi (Averrhoa bilimbi L.). Revista Brasileira de Fruticultura 23(2): 421-423.

5. Bakul G, Unni VN, Seethaleksmy NV, Mathew A, Rajesh R, et al. (2013) Acute oxalate nephropathy due to 'Averrhoa bilimbi' fruit juice ingestion. Indian J Nephrol 23(4): 297-300.

6. Nair S, George J, Kumar S, Gracious N (2014) Acute Oxalate Nephropathy following Ingestion of Averrhoa bilimbi Juice. Case Rep Nephrol 2014: 240936 .

7. Rajat Das Gupta MI, Debashis Datta, Suranjan Kumar (2016) Acute Oxalate Nephropathy Due to Bilimbi Poisoning: A Case Report. International Journal of Medical Students 4(1): 33-35.
ISSN: 2574-1241

DOI: 10.26717/BJSTR.2019.19.003314

Sukit Raksasuk. Biomed J Sci \& Tech Res

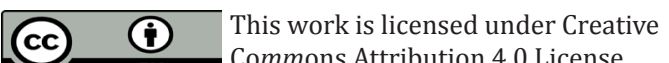

Submission Link: https://biomedres.us/submit-manuscript.php

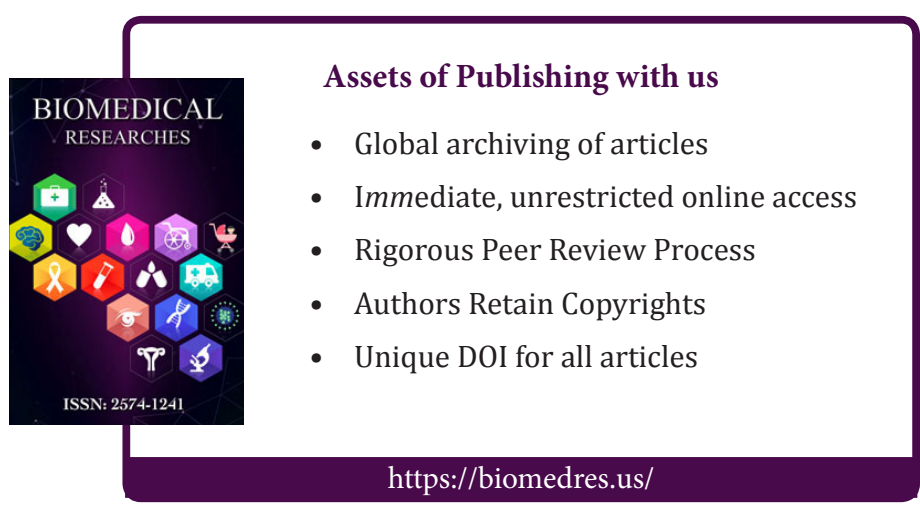

